\title{
Hematological changes in Eleginops maclovinus during an experimental Caligus rogercresseyi infestation
}

\author{
Alterações hematológicas em Eleginops maclovinus durante uma infestação \\ experimental com Caligus rogercresseyi
}

\author{
Patricio Peña-Rehbein ${ }^{1 *}$; Karin Ruiz²; Alexander Ortloff'; María Isabel Pizarro²; Carolina Navarrete ${ }^{3}$ \\ ${ }^{1}$ Escuela de Medicina Veterinaria, Universidad Católica de Temuco - UCT, Temuco, Chile \\ ${ }^{2}$ Estación Experimental Quillaipe, Fundación Chile, Puerto Montt, Chile \\ ${ }^{3}$ Not specified
}

Received April 14, 2013

Accepted August 14, 2013

\begin{abstract}
Eleginops maclovinus has been an important fishery resource in Chile since 1957. Caligus rogercresseyi is one of the most prevalent ectoparasite species found on E. maclovinus. Hematocrit, hemoglobin level, red blood cell count (RBC), white blood cell count (WBC), mean corpuscular volume (MCV), mean corpuscular hemoglobin (MCH), mean corpuscular hemoglobin concentration $(\mathrm{MCHC})$ and differential white blood cell count were determined before and after an experimental infestation with $C$. rogercresseyi. We found significant differences in the hemoglobin level, WBC, $\mathrm{MCV}, \mathrm{MCH}, \mathrm{MCHC}$, hematocrit level and RBC between infested and uninfested fish. Furthermore correlations between number of $C$. rogercresseyi with hematocrit, $\mathrm{MCHC}$, neutrophil, eosinophil and lymphocyte counts were found. Hematological reference ranges of E. maclovinus in captivity conditions were also established.
\end{abstract}

Keywords: Blood parameters, erythrocytes, leukocytes.

\section{Resumo}

Eleginops maclovinus tem sido um importante recurso pesqueiro no Chile desde 1957. Caligus rogercresseyi é uma das espécies ectoparasitas mais comumente encontradas em E. maclovinus. Hematócrito, nível de hemoglobina, contagem de eritrócitos, contagem de leucócitos, volume corpuscular médio (VCM), hemoglobina corpuscular média (HCM), concentração de hemoglobina corpuscular média (CHCM) e contagem diferencial de leucócitos foram determinadas antes e após uma infestação experimental com $C$. rogercresseyi. Foram encontradas diferenças significativas no nível de hemoglobina, leucócitos, VCM, HCM, CHCM, hematócrito e eritrócitos entre peixes infestados e não infestados. Além disso, foram encontradas correlaçóes entre o número de C. rogercresseyi com hematócrito, CHCM, neutrófilos, eosinófilos e linfócitos. Foram estabelecidos intervalos de referência para E. maclovinus em condiçóes de cativeiro.

Palavras-chave: Parâmetros sanguíneos, eritrócitos, leucócitos.

\section{Introduction}

The Chilean rock cod, also known as robalo (Eleginops maclovinus), is a common fish in littoral zones, estuaries and rivers (under tidal effects) of southern South America, including the Falkland islands (PEQUEÑO et al., 2010). Although this species is traditionally considered an opportunistic benthic omnivore, recent research indicates that juveniles and adults are opportunistic carnivores capable of feeding in both marine and freshwater environments (EASTMAN; LANNOO, 2008). E. maclovinus is a coastal species generally associated with estuarine systems, has been exploited as a fishery resource in Chile since

\footnotetext{
*Corresponding author: Patricio Peńa-Rehbein

Escuela de Medicina Veterinaria, Facultad de Recursos Naturales, Universidad

Católica de Temuco - UCT, Manuel Montt 056, Temuco, Chile

e-mail: ppenar@uct.cl
}

1957 (GACITÚA et al., 2008) and also has a great potential to be farmed (VALENZUELA et al., 1999).

Caligus species is found in continental waters on native fish (E. maclovinus) as well as on a cultured species, Oncorhynchus mykiss, from the south of Chile (CARVAJAL et al., 1998). C. rogercresseyi (Copepoda: Caligidae) is one of the most prevalent ectoparasite species found on E. maclovinus (CARVAJAL et al., 2001; HENRIQUEZ et al., 2011). Parasites negatively influence host fitness, and in response, hosts develop anti-parasitic defenses, for example, a functional immune system, to reduce the fitness cost induced by parasitism (SHELDON; VERHULST, 1996). Sea louse cause a local inflammatory response and blood loss at the site of attachment but do not appear to suppress host defense mechanisms during the early stages of infestation (TAVARES-DIAS et al., 2007; 
WAGNER et al., 2008). Parasitic infestations can influence blood parameters, such as anemia and white cells count unbalances in other host fishes (HORTON; OKAMURA, 2003; MARTINS et al., 2004; SILVA-SOUZA et al., 2000; TAVARES-DIAS et al., 1999, 2002, 2007; WAGNER et al., 2008).

The aim of this work is to study the hematological changes in E. maclovinus caused by $C$. rogercresseyi-induced experimental infestation.

\section{Materials and Methods}

The experimental hatchery of Fundación Chile in Quillaipe (Región de los Lagos, Chile) has E. maclovinus stocks that were grown since hatching. In this study $160 \mathrm{E}$. maclovinus (weight $=488 \pm 138 \mathrm{~g}$, length $=32.9 \pm 2.89 \mathrm{~cm}$ ) belonging to this group were used. They have always been fed with an Ewos transfer commercial diet. Prior to the experiment fish were acclimatized to the experimental tank for two weeks. During acclimatization and experimental periods, fish were maintained in a $3 \mathrm{~m}^{3}$ tank with a density of $26.03 \mathrm{~kg} \mathrm{~m}^{-3}$. The maximum density for E. maclovinus farming is $30 \mathrm{~kg} \mathrm{~m}^{-3}$ (Fundación Chile unpublished results). The water temperature during the experiment was $12.7 \pm 0.8^{\circ} \mathrm{C}$. Fish were infested with copepodid stage $C$. rogercresseyi parasites (150 copepodid/fish), and infestation was maintained up to 4 weeks post-infestation (wpi).

Blood samples were taken from the caudal vessel (WEISS; WARDROP, 2010) one week pre (basal) and 2, 3 and 4 weeks post infection (wpi) ( $n=40$ per each sample time). The fish were sedated using benzocaine $\left(50 \mathrm{mg} \mathrm{L}^{-1}\right)$ prior to bleeding. Once the fishes were sampled $(n=40)$ they were placed in a different tank to avoid fish reuse; afterwards water level corrections were performed to keep a constant density during the experiment.

Blood samples were stored in heparinized Eppendorf tubes that were transported at $4{ }^{\circ} \mathrm{C}$ and analyzed within $12 \mathrm{~h}$ of collection at the Catholic University of Temuco. The hematocrit, hemoglobin level, red blood cell count (RBC), white blood cell count (WBC), mean corpuscular volume (MCV), mean corpuscular hemoglobin $(\mathrm{MCH})$, mean corpuscular hemoglobin concentration (MCHC) and differential white cell count were determined using standard methods (BAIN et al., 2011; TODD et al., 1979).
Statistical analysis was performed using a one-way ANOVA and the Bonferroni post-test to make comparisons between the groups infested and uninfested. Associations of parasite count with neutrophil, eosinophil, and lymphocyte counts; hematocrit; and MCHC levels were tested using the Spearman correlation (rs) and linear regression. Statistical significance between the groups was indicated by $\mathrm{p}<0.05$. All statistical analyses were performed using GraphPad Prism v5.0 (GraphPad Software Inc, CA, USA).

\section{Results}

The $C$. rogercresseyi infestation site was the skin of $E$. maclovinus. The mean parasite number \pm standard deviation per fish at $2^{\text {nd }}$ wpi was $6.73 \pm 5.71$, at $3^{\text {rd }}$ wpi was $4.14 \pm 3.58$ and at the end of experiment was $1.11 \pm 1.06$.

The mean values and ranges of the blood parameters and white blood cells counts for uninfested and $C$. rogercresseyiinfested E. maclovinus are shown in Table 1. Table 2 describes the hematological reference ranges in E. maclovinus under cultivation.

Our results showed significant differences between infested and uninfested fish in hemoglobin levels $(\mathrm{p}=0.0104 ; \mathrm{df}=154 ; \mathrm{F}=3.883)$, WBC counts $(\mathrm{p}=<0.0001 ; \mathrm{df}=154 ; \mathrm{F}=37.12), \mathrm{MCV}(\mathrm{p}=<0.0001$; $\mathrm{df}=154 ; \mathrm{F}=8.3), \mathrm{MCH}(\mathrm{p}=<0.0001 ; \mathrm{df}=154 ; \mathrm{F}=21), \mathrm{MCHC}$ $(\mathrm{p}=<0.0001 ; \mathrm{df}=154 ; \mathrm{F}=25)$, hematocrit $(\mathrm{p}=<0.0001 ; \mathrm{df}=154 ;$ $\mathrm{F}=9.935)$ and $\mathrm{RBC}$ counts $(\mathrm{p}=<0.0001 ; \mathrm{df}=154 ; \mathrm{F}=14.47)$. No significant differences were observed in lymphocyte, neutrophil, eosinophil, basophil and monocyte counts.

Infested fish show an increase in WBC counts up to the $3^{\text {rd }}$ wpi and an increase in eosinophils and basophils in the second week, with a subsequent decline to the $4^{\text {th }}$ wpi, a decrease in neutrophils over all $4 \mathrm{wpi}$, an increase in lymphocytes at $4 \mathrm{wpi}$, and a decrease in monocytes up to the $3^{\text {rd }}$ wpi followed by a slight increase in the last wpi. Red blood cell parameters (hemoglobin, $\mathrm{MCV}, \mathrm{MCH}$ and $\mathrm{MCHC}$ ) increased during infestation; however, RBC count and hematocrit decreases during infestation. The most common leukocytes in uninfested group (basal) were lymphocytes, followed by neutrophils, monocyte, basophils and a small perceptual of eosinophils. However, in the infested group, the most abundant cell types were lymphocytes, neutrophils and eosinophils (Table 1).

Table 1. Hematological parameters of uninfested and Caligus rogercresseyi-infested Eleginops maclovinus. Mean \pm standard deviation (SD). Different lowercase letters indicate significant differences.

\begin{tabular}{|c|c|c|c|c|}
\hline \multirow[t]{2}{*}{ Parameters } & Basal & $2^{\text {nd }}$ wpi & $3^{\text {rd }}$ wpi & $4^{\text {th }}$ wpi \\
\hline & $(n=40)$ & $(n=40)$ & $(n=40)$ & $(n=40)$ \\
\hline $\mathrm{RBC}\left(\mathrm{x} 10^{6} / \mu \mathrm{L}\right)$ & $1.15 \pm 0.25 \mathrm{a}$ & $0.90 \pm 0.15 \mathrm{~b}$ & $0.92 \pm 0.17 \mathrm{~b}$ & $0.89 \pm 0.22 \mathrm{~b}$ \\
\hline Hematocrit (\%) & $51.2 \pm 7.71 \mathrm{a}$ & $49.5 \pm 2.86 \mathrm{ac}$ & $47.8 \pm 3.17 b c$ & $45.3 \pm 4.22 \mathrm{~b}$ \\
\hline Hemoglobin $\left(\mathrm{g} \mathrm{dL}^{-1}\right)$ & $7.97 \pm 1.16 \mathrm{a}$ & $8.51 \pm 0.83 \mathrm{a}$ & $8.3 \pm 0.99 \mathrm{a}$ & $8.71 \pm 0.92 \mathrm{~b}$ \\
\hline MCV (fL) & $458 \pm 76 \mathrm{a}$ & $564 \pm 95.4 \mathrm{~b}$ & $531 \pm 78.2 b$ & $540 \pm 143 b$ \\
\hline $\mathrm{MCH}(\mathrm{pg})$ & $72.1 \pm 16.4 \mathrm{a}$ & $96 \pm 12.5 \mathrm{bc}$ & $92.1 \pm 14.7 \mathrm{~b}$ & $104 \pm 26.6 \mathrm{c}$ \\
\hline $\operatorname{MCHC}\left(\mathrm{g} \mathrm{dL}^{-1}\right)$ & $15.8 \pm 2.42 \mathrm{a}$ & $17.2 \pm 1.62 \mathrm{~b}$ & $17.4 \pm 1.6 \mathrm{~b}$ & $19.3 \pm 1.06 \mathrm{c}$ \\
\hline WBC $\left(x 10^{3} / \mu \mathrm{L}\right)$ & $1.47 \pm 0.24 \mathrm{a}$ & $1.85 \pm 0.28 \mathrm{~b}$ & $2.25 \pm 0.53 c$ & $2.19 \pm 0.34 \mathrm{~cd}$ \\
\hline Lymphocytes (\%) & $75.3 \pm 7.84 \mathrm{a}$ & $82.6 \pm 5.86 b$ & $86.8 \pm 6.53 b$ & $87.3 \pm 4.84 b$ \\
\hline Neutrophils (\%) & $12.5 \pm 4.93 \mathrm{a}$ & $11 \pm 4.76 \mathrm{a}$ & $9.63 \pm 4.35 \mathrm{a}$ & $9.03 \pm 5.55 \mathrm{a}$ \\
\hline Eosinophils (\%) & $1.0 \pm 0 \mathrm{a}$ & $7.31 \pm 5.48 \mathrm{a}$ & $4.23 \pm 3.44 \mathrm{a}$ & $4.45 \pm 3.32 \mathrm{a}$ \\
\hline Monocytes (\%) & $10.9 \pm 5.72 \mathrm{a}$ & $1.88 \pm 1.43 \mathrm{~b}$ & $1.0 \pm 0 \mathrm{~b}$ & $2.87 \pm 2.64 \mathrm{~b}$ \\
\hline Basophils (\%) & $2.63 \pm 2.64 \mathrm{a}$ & $3 \pm 1.41 \mathrm{a}$ & $1.0 \pm 0 \mathrm{a}$ & $1.0 \pm 0 \mathrm{a}$ \\
\hline
\end{tabular}

weeks post infection (wpi). 

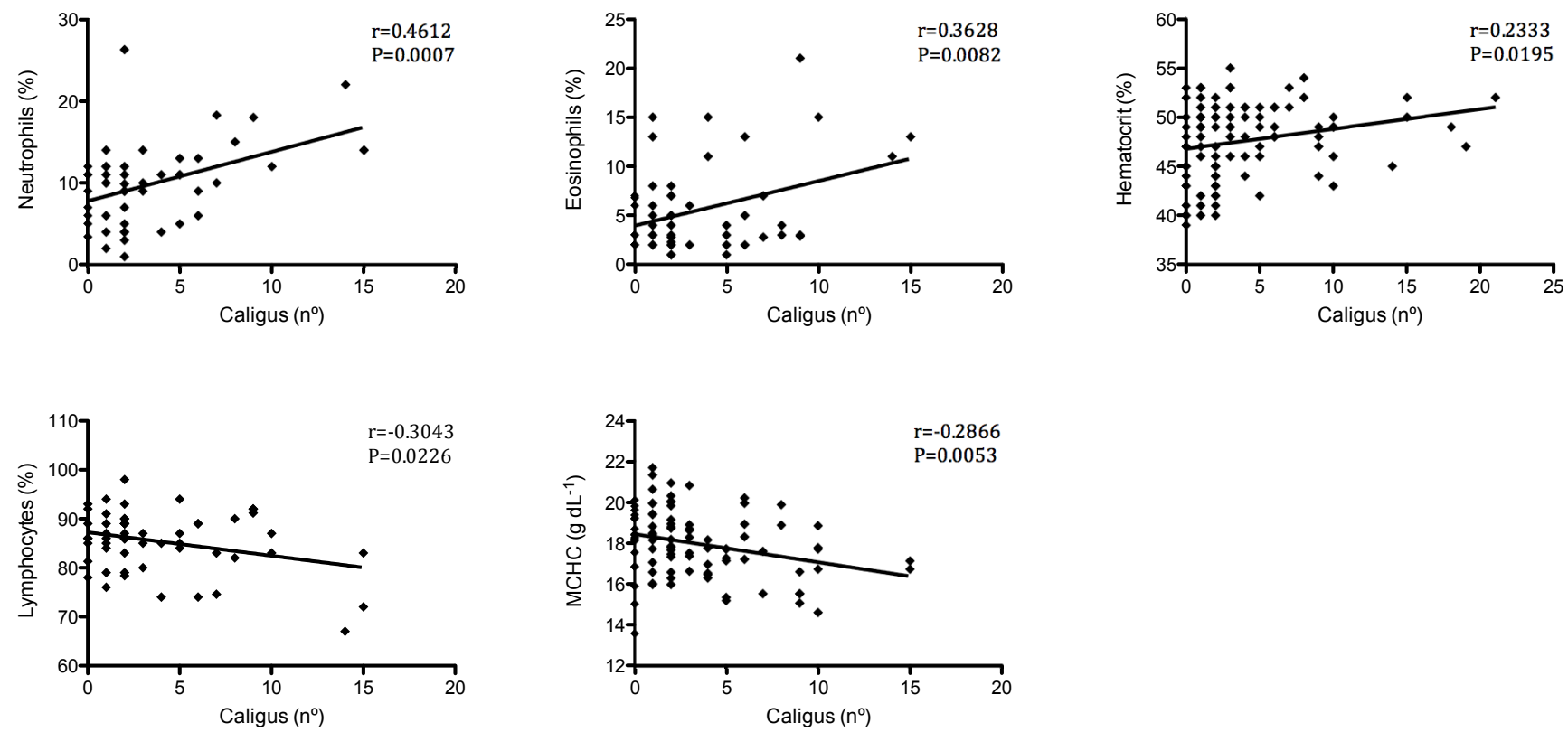

Figure 1. Correlations between Caligus rogercresseyi number and hematological parameters of Eleginops maclovinus.

Table 2. Reference ranges of hematological parameters in Eleginops maclovinus $(\mathrm{n}=40)$ under farm conditions. Lower $\left(25^{\text {th }}\right)$ and upper percentiles $\left(75^{\text {th }}\right)$.

\begin{tabular}{lc}
\hline \multicolumn{1}{c}{ Parameters } & Uninfested Range $\left(\mathbf{2 5}^{\text {th }} \mathbf{7 5}^{\text {th }}\right)$ \\
\hline RBC $\left(\mathrm{x} 10^{6} / \mu \mathrm{L}\right)$ & $0.90-1.30$ \\
Hematocrit $(\%)$ & $38.0-57.8$ \\
Hemoglobin $\left(\mathrm{g} \mathrm{dL}^{-1}\right)$ & $7.25-8.84$ \\
MCV $(\mathrm{fL})$ & $414-491$ \\
MCH $(\mathrm{pg})$ & $58.7-80.4$ \\
MCHC $(\mathrm{g} \mathrm{dL}-1)$ & $14.2-17.0$ \\
WBC $\left(\mathrm{x} 10^{3} / \mu \mathrm{L}\right)$ & $1.26-1.65$ \\
Lymphocytes $(\%)$ & $68.0-82.9$ \\
Neutrophils $(\%)$ & $9.0-15.0$ \\
Eosinophils $(\%)$ & $1.0-1.0$ \\
Monocytes $(\%)$ & $6.85-14.0$ \\
Basophils $(\%)$ & $1.0-3.0$ \\
\hline
\end{tabular}

Our results demonstrate that the number of $C$. rogercresseyi in the body was correlated with the neutrophil counts $(r=0.4612$; $\mathrm{p}=0.0007)$, eosinophil counts $(\mathrm{r}=0.3628 ; \mathrm{p}=0.0082)$, hematocrit levels $(\mathrm{r}=0.2333 ; \mathrm{p}=0.0195)$, MCHC $(\mathrm{r}=-0.2866 ; \mathrm{p}=0.053)$ and lymphocyte counts $(\mathrm{r}=-0.3043 ; \mathrm{p}=0.0226)$. No correlation was observed between the $C$. rogercresseyi number and red blood cell counts, hemoglobin levels, MVC, MCH, and white blood cell, monocyte and basophil counts (Figure 1).

\section{Discussion}

Studies performed by Valenzuela et al. (1999) and Valenzuela et al. (2003) have characterized blood cells from wild fish native to Chile. To date there are no studies of the differences in the hematologic parameters between uninfested and infested captive robalo $E$. maclovinus with $C$. rogercresseyi.
The infestation site by $C$. rogercresseyi was the skin of E. maclovinus, this is consistent with Nolan et al. (2000), Costello (2006), Hamilton-West et al. (2012) and Venmathi Maran et al. (2012).

When compared our infested fish with data from Valenzuela et al. (1999), no differences was found in lymphocyte, eosinophil and monocyte counts, this suggests that the study by Valenzuela et al. (1999) was made with wild infested E. maclovinus. On the other hand, we found statistically significant differences in lymphocyte $(\mathrm{p}<0.0001, \mathrm{df}=185, \mathrm{~F}=23.1)$, eosinophil $(\mathrm{p}<0.0001, \mathrm{df}=185$, $\mathrm{F}=15.1)$ and monocyte counts $(\mathrm{p}<0.0001, \mathrm{df}=185, \mathrm{~F}=78.9)$ when compared Valenzuela et al. (1999) results with our uninfested (basal) fish group. The values of uninfested group are proposed as reference ranges for uninfested $E$. maclovinus maintained in captivity (Table 2). Blood parameters, although not regularly used in fish medicine, can provide substantial diagnostic information once reference intervals are established.

In both the infested and basal (uninfested) groups, we found that lymphocytes are the most abundant leukocytes in the peripheral blood; however, eosinophils were scarce in the uninfested fishes but abundant in the infested ones, which correlates with other studies in fishes (ALVAREZ-PELLITERO, 2008; EZE EVELYN et al., 2012; PIERRARD et al., 2012; RUANE et al., 2000; SILVA-SOUZA et al., 2000). Neutrophils decrease steadily during the 4 weeks of infestation, which is consistent with a study by Tavares-Dias et al. (2008). This decrease indicates that neutrophils are often the first leukocytes to migrate to the site of parasite infestation (TAVARES-DIAS et al., 2008; WITESKA et al., 2010). WBC counts increase significantly in infested $E$. maclovinus at 2, 3 and 4 wpi, correlating with the studies by Jori and Mohamad (2008) and Harikrishnan et al. (2012). The RBC counts decrease during the $C$. rogercresseyi infestation, which is similar to studies of other parasites (HORTON; OKAMURA, 2003; MARTINS et al., 2004; TAVARES-DIAS et al., 2002). Hematocrit and electrolyte 
levels are secondary indicators of chronic stress, indicating the osmoregulatory status of the fish (TAVARES-DIAS et al., 2007). The hematocrit reduction in infested fish can be explained by osmoregulatory failure as a result of exposed lesions (GRIMNES; JAKOBSEN, 1996) or blood ingestion (JONES; GRUTTER, 2005).

Higher values of $\mathrm{MCV}, \mathrm{MCH}$ and $\mathrm{MCHC}$ was found in infested fish when compared to uninfested fish, this is probably due to the continued development in RBC which increase in size and hemoglobin content with time (WEISS; WARDROP, 2010).

Positive correlations found between $C$. rogercresseyi number and neutrophil count, could be explained by the hyperplastic and inflammatory responses involving rich neutrophil infiltration as response to Lepeophtheirus salmonis observed in salmonids (WOO; BUCHMANN, 2011). The positive correlation with eosinophils counts is due to that eosinophils are frequently involved in parasite disease responses (ALVAREZ-PELLITERO, 2008; THRALL et al., 2012). So, hematocrit positive correlation with parasite number is consistent with osmoregulatory failure as a result of exposed lesions or blood ingestion (GRIMNES; JAKOBSEN, 1996; JONES; GRUTTER, 2005). Negative correlation between number of C. rogercresseyi and $\mathrm{MCHC}$ is probably an indication of $\mathrm{RBC}$ swelling and/or a decrease in hemoglobin synthesis (KUMAR; RAMULU, 2013). The negative correlation of lymphocytes count with $C$. rogercresseyi is explained by the migration of lymphocytes into peripheral tissues such as skin and gills which has been reported in Atlantic salmon infected with adult L. salmonis and other salmonids (RUANE et al., 2000).

In conclusion, this study has demonstrated differences between Caligus rogercresseyi-infected and uninfected $E$. maclovinus in the hematological parameters RBC and WBC counts, hemoglobin, $\mathrm{MCV}, \mathrm{MCH}, \mathrm{MCHC}$ and hematocrit. The WBC count increased during infection and were mainly composed by lymphocytes, neutrophils, and eosinophils. Neutrophils, eosinophils and hematocrit increased with parasites number, confirming the importance of these leukocytes in the response against $C$. rogercresseyi. The Chilean rock cod, also known as robalo

\section{References}

Alvarez-Pellitero P. Fish immunity and parasite infections: from innate immunity to immunoprophylactic prospects. Vet Immunol Immunopathol 2008; 126(3-4): 171-198. http://dx.doi.org/10.1016/j. vetimm.2008.07.013

Bain BJ, Bates I, Laffan MA, Lewis SM. Dacie and Lewis Practical Haematology. 11th ed. Philadelphia: Churchill Livingstone; 2011.

Carvajal J, González L, George-Nascimento M. Native sea lice (Copepoda: Caligidae) infestation of salmonids reared in netpen systems in southern Chile. Aquaculture 1998; 166(3-4): 241-246. http://dx.doi. org/10.1016/S0044-8486(98)00301-9

Carvajal J, Ruiz G, Sepúlveda F. Symbiotic relationship between Udonella sp. (Monogenea) and Caligus rogercresseyi (Copepoda), a parasite of the chilean rock cod Eleginops maclovinus. Arch Med Vet 2001; 33(1): 31-36. http://dx.doi.org/10.4067/S0301-732X2001000100003
Costello MJ. Ecology of sea lice parasitic on farmed and wild fish. Trends Parasitol 2006; 22(10): 475-483. http://dx.doi.org/10.1016/j. pt.2006.08.006

Eastman JT, Lannoo MJ. Brain and sense organ anatomy and histology of the Falkland Islands mullet, Eleginops maclovinus (Eleginopidae), the sister group of the Antarctic notothenioid fishes (Perciformes: Notothenioidei). J Morphol 2008; 269(1): 84-103.

Eze Evelyn M, Ezeiruaku FC, Ukaji DC. Experiential relationship between malaria parasite density and some haematological parameters in malaria infected male subjects in Port Harcourt, Nigeria. Glob J Health Sci 2012; 4(4): 139-148. http://dx.doi.org/10.5539/gjhs.v4n4p139

Gacitúa S, Oyarzún C, Veas R. Análisis multivariado de la morfometría y merística del robalo Eleginops maclovinus (Cuvier, 1830). Rev Biol Mar Oceanogr 2008; 43(3): 491-500. http://dx.doi.org/10.4067/S071819572008000300008

Grimnes A, Jakobsen PJ. The physiological effects of salmon lice infection on post-smolt of Atlantic salmon. J Fish Biol 1996; 48(6): 1179-1194. http://dx.doi.org/10.1111/j.1095-8649.1996.tb01813.x

Hamilton-West C, Arriagada G, Yatabe T, Valdés P, Hervé-Claude LP, Urcelay S. Epidemiological description of the sea lice (Caligus rogercresseyi) situation in southern Chile in August 2007. Prev Vet Med 2012; 104(3-4): 341-345. http://dx.doi.org/10.1016/j. prevetmed.2011.12.002

Harikrishnan R, Kim J, Balasundaram C, Heo M. Dietary supplementation with chitin and chitosan on haematology and innate immune response in Epinephelus bruneus against Philasterides dicentrarchi. Exp Parasitol 2012; 131(1): 116-124. http://dx.doi.org/10.1016/j. exppara.2012.03.020

Henriquez VP, Gonzalez MT, Licandeo R, Carvajal J. Metazoan parasite communities of rock cod Eleginops maclovinus along southern Chilean coast and their use as biological tags at a local spatial scale. J Fish Biol 2011; 79(7): 1851-1865. http://dx.doi.org/10.1111/j.10958649.2011.03126.x

Horton T, Okamura B. Post-haemorrhagic anaemia in sea bass, Dicentrarchus labrax (L.), caused by blood feeding of Ceratothoa oestroides (Isopoda: Cymothoidae).J Fish Dis 2003; 26(7): 401-406. http://dx.doi. org/10.1046/j.1365-2761.2003.00476.x

Jones CM, Grutter AS. Parasitic isopods (Gnathia sp.) reduce haematocrit in captive blackeye thicklip (Labridae) on the Great Barrier Reef. J Fish Biol 2005; 66(3): 860-864. http://dx.doi.org/10.1111/j.00221112.2005.00640.x

Jori MM, Mohamad ET. The effect of Hamatopeduncularia sp. and Caligus sp. on some blood parameters of Arius bilineatus (Val., 1840). Mesopot J Mar Sci 2008; 23(2): 269-277.

Kumar MP, Ramulu KS. Haematological changes in Pangasius hypophthalmus infected with Aeromonas hydrophila. Int J Food, Agriculture Vet Sci 2013; 3(1): 70-75.

Martins ML, Tavares-Dias M, Fujimoto RY, Onaka EM, Nomura DT. Haematological alterations of Leporinus macrocephalus (Osteichtyes: Anostomidae) naturally infected by Goezia leporini (Nematoda: Anisakidae) in fish pond. Arq Bras Med Vet Zootec 2004; 56(5): 640-646. http://dx.doi.org/10.1590/S0102-09352004000500011

Nolan DT, Ruane NM, Van Der Heijden Y, Quabius ES, Costelloe J, Bonga SEW. Juvenile Lepeophtheirus salmonis (Krøyer) affect the skin and gills of rainbow trout Oncorhynchus mykiss (Walbaum) and the host 
response to a handling procedure. Aquacult Res 2000; 31(11): 823-833. http://dx.doi.org/10.1046/j.1365-2109.2000.00515.x

Pequeño G, Pavés H, Bertrán C, Vargas-Chacoff L. Seasonal limnetic feeding regime of the "robalo" Eleginops maclovinus (Valenciennes 1830), in the Valdivia river, Chile. Gayana (Concepc), 2010; 74(1): 47-56. http:// dx.doi.org/10.4067/S0717-65382010000100008

Pierrard MA, Roland K, Kestemont P, Dieu M, Raes M, Silvestre F. Fish peripheral blood mononuclear cells preparation for future monitoring applications. Anal Biochem 2012; 426(2): 153-165. http://dx.doi. org/10.1016/j.ab.2012.04.009

Ruane NM, Nolan DT, Rotllant J, Costelloe J, Wendelaar Bonga SE. Experimental exposure of rainbow trout Oncorhynchus mykiss (Walbaum) to the infective stages of the sea louse Lepeophtheirus salmonis (Krøyer) influences the physiological response to an acute stressor. Fish Shellfish Immunol 2000; 10(5): 451-463.

Sheldon BC, Verhulst S. Ecological immunology: costly parasite defences and trade-offs in evolutionary ecology. Trends Ecol Evol 1996; 11(8): 317-321. http://dx.doi.org/10.1016/0169-5347(96)10039-2

Silva-Souza AT, Almeida SC, Machado PM. Effect of the infestation by Lernaea cyprinacea Linnaeus, 1758 (Copepoda, Lernaeidae) on the leucocytes of Schizodon intermedius Garavello \& Britski, 1990 (Osteichthyes, Anostomidae). Rev Bras Biol 2000; 60(2): 217-220. http:// dx.doi.org/10.1590/S0034-71082000000200004

Tavares-Dias M, Martins ML, Kronka SN. Evaluation of the haematological parameters in Piaractus mesopotamicus Holmberg (Osteichthyes, Characidae) with Argulus sp. (Crustacea, Branchiura) infestation and treatment with organophosphate. Rev Bras Zool 1999; 16(2): 553-555. http://dx.doi.org/10.1590/S0101-81751999000200019

Tavares-Dias M, Moraes FR, Martins ML. Hematological Assessment in Four Brazilian Teleost Fish with Parasitic Infections, Collected in Feefishing from Franca, São Paulo, Brazil. Bol Inst Pesca 2008; 34(2): 189-196.
Tavares-Dias M, Moraes FR, Martins ML, Santana AE. Haematological changes in Oreochromis niloticus (Osteichthyes: Cichlidae) with gill ichthyophthiriasis and saprolegniosis. Bol Inst Pesca 2002; 28(1): 9.

Tavares-Dias M, Moraes FR, Onaka E, Rezende PCB. Changes in blood parameters of hybrid tambacu fish parasitized by Dolops carvalho (Crustacea, Branchiura), a fish louse. Vet Arhiv 2007; 77(4): 355-363.

Thrall MA, Weiser G, Allison RW, Campbell TW. Veterinary Hematology and Clinical Chemistry. 2nd ed. Ames: Wiley-Blackwell; 2012.

Todd J, Sanford A, Davison I. Clinical Diagnosis and Management by Laboratory Methods. 16th ed. Philadelphia: Saunders; 1979.

Valenzuela A, Oyarzún C, Silva V. Células sanguíneas de Schroederichthys chilensis (Guichenot 1848) (Elasmobranchii, Scyliorhinidae): la serie blanca. Gayana (Concepc) 2003; 67(1): 130-136. http://dx.doi. org/10.4067/S0717-65382003000100018

Valenzuela A, Silva V, Oyarzún C. Caracterización cualitativa y cuantitativa de células sanguíneas de robalo Eleginops maclovinus (Valenciennes, 1830) (Pisces, Eleginopsidae) en la desembocadura del río Biobio. Rev Biol Mar Oceanogr 1999; 34(2): 261-267.

Venmathi Maran BA, Oh SY, Soh HY, Choi HJ, Myoung JG. Caligus sclerotinosus (Copepoda: Caligidae), a serious pest of cultured red seabream Pagrus major (Sparidae) in Korea. Vet Parasitol 2012; 188(3-4): 355-361. http://dx.doi.org/10.1016/j.vetpar.2012.03.023

Wagner GN, Fast MD, Johnson SC. Physiology and immunology of Lepeophtheirus salmonis infections of salmonids. Trends Parasitol 2008; 24(4): 176-183. http://dx.doi.org/10.1016/j. pt.2007.12.010

Weiss D, Wardrop K. Schalm's Veterinary Hematology. 6th ed. Singapore: Wiley-Blackwell; 2010

Witeska M, Kondera E, Lugowska K. The effects of ichthyophthiriasis on some haematological parameters in common carp. Turk J Vet Anim Sci 2010; 34(3): 267-271.

Woo P, Buchmann K. Fish Parasites: Pathobiology and Protection. CAB International; 2011. 